\title{
CHEMICAL SENSOR BASED ON TETRADECIL AMMONIUM NITRATE
}

\author{
M. DE LOS A. ARADA PÉREZI, M. YAZDANI-PEDRAM² \\ ${ }^{\prime}$ Department of Analytical Chemistry, Eastern University of Cuba, Santiago de Cuba. \\ Ave Patricio Lumumba s/n, 90500, Rpto Jimenez, Santiago de Cuba, Cuba. \\ ${ }^{2}$ Department of Organic and Physical Chemistry, Faculty of Chemical and Pharmaceutical Sciences, University of Chile, \\ S. Livingstone 1007, Independencia, Santiago, Chile. \\ (Received: May 29, 2012 - Accepted: November 21, 2012)
}

\begin{abstract}
The construction and evaluation of an all-solid-state type electrode selective to nitrate based on poly(vinyl chloride) (PVC) as polymeric membrane, diethyl phthalate as plasticizer and tetradecilammonium nitrate (TDAN) as positively charged ionophore is reported. The constructed electrode showed fast potentiometric response to nitrate in the concentration range from $10^{-6}$ to $10^{-2} \mathrm{~mol} / \mathrm{dm}^{3}$ with Nernstian slope of $-73.15 \pm 0.28 \mathrm{mV} /$ decade, response time of $15 \mathrm{~seconds}$ and lifetime of 1 month.
\end{abstract}

Keywords: Nitrate-selective membranes, positively charged carrier, all-solid-state ISE, quaternary ammonium salt, chemical sensor.

\section{INTRODUCTION}

A variety of ISE designs ranging from centimetre-long probes to miniaturized micrometer self-contained solid-state chemical sensor arrays [1] constitute the basis of modern potentiometric measurements that have become increasingly important in monitoring of industrial process control and determination of heavy metals in environmental samples for low detection limit applications at trace levels [2-4] constitute just a few examples at the centre of modern potentiometric methods.

Numerous analytical methods for determination of $\mathrm{NO}_{3}^{-}$in different type of samples have been described. They include kinetic, chromatographic, potentiometric, amperometric and spectrophotometric methods and in conditions of flow [5-12]. These methods, in addition to the need of previous treatment of the samples, are quite laborious so that they require rather long time for the analysis to be accomplished. These inconvenient could be simplified by using potentiometric method employing ion-selective electrodes (ISE) [13-19]. The potentiometric method, in addition to be an economical method, offers many advantages over other more sophisticated analytical methods for nitrate ion determination. These advantages include fast sample determination, ease of the elimination of interfering chloride ion by using ISA $\mathrm{Pb}$ or ISA Ag solutions for ionic force adjustment, simplicity of the method and the possibility of determination in very small sample volume. Moreover, the simplicity of the measurements allows the onsite sampling. The specific field which it is possible to accomplish the determination of this ion is ample, among which are soil, foods, plants, drinking water, etc.

In this work an ISE for nitrate was constructed by using the quaternary ammonium salt tetradecilammonium nitrate (TDAN) as ionophore, PVC as polymeric matrix and diethyl phthalate (DEP) as plasticizer. Some properties of the electrode such as selectivity coefficient, practical detection limit and lower limit of linear response and life-time was studied.

\section{EXPERIMENTAL}

\subsection{Materials and methods}

All the reagents used in this study were of analytical grade. Poly (vinylchloride) (PVC) from Fluka was used as polymeric matrix. The plasticizer used was diethyl phthalate (DEP) from Aldrich. Tetrahydrofurane (THF) was analytical grade from Merck. Tetradecilammonium nitrate (TDAN) employed as ionophore was synthesized in our laboratory. The elemental analysis of the TDAN salt was carried out at the University of Rome, La Sapienza, using a Carlo-Erba Elemental Analyzer model Ea +1110 . Its melting point was determined in the department of organic chemistry of the University of Rome using a melting point apparatus by $\mathrm{W}$. Buchi.

ATR-FT-IR spectra were obtained using a Genesis- Mattson spectrophotometer in the frequency range of $4000-400 \mathbf{~ c m}^{-1}$. The ATR determination was carried out by using a multiple internal reflection accessory from Unicam with internal reflection elements (IRE) at $45^{\circ}$ of $\mathrm{ZnSe}$ and a detector of mercuty-cadmium-telurim (TCM).

The water used in this work was bidistilled water with conductivity of less than $2 \mu \mathrm{S} / \mathrm{cm}^{-1}$. The epoxy conducting resin was prepared by mixing a commercial two component epoxy adhesive form Ciba-Geigy with graphite powder from Merck as already described by Arada Pérez et.al. [20] for nitrate sensors obtaining a resistance of $\leq 2 \mathrm{k} \Omega$.

A digital Hanna $\mathrm{pH}$ meter model 213 with a precision of $\pm 0.1 \mathrm{mV}$ was used for measuring the potential difference between reference and indicator electrodes. The reference electrode used in this study was an $\mathrm{Ag} / \mathrm{AgCl} \mathrm{HI}$ 5311 double junction electrode and a solution of $0.1 \mathrm{~mol} / \mathrm{dm}^{3}$ of $\mathrm{K}_{2} \mathrm{SO}_{4}$ was employed in the external electrode compartment and a hot plate-stirrer Jenway model 1000 LT.

\subsubsection{Preparation of the membrane}

The prepared membranes contained $7 \mathrm{Wt} . \%$ of tetradecilammonium nitrate (TDAN) as ionophore, $64 \mathrm{Wt} . \%$ of diethyl phthalate as plasticizer and $29 \mathrm{Wt} . \%$ of PVC as the polymeric matrix. The preparation of the electrode was carried out in a similar manner as the method used for the construction of the all-solid-state ion selective electrodes reported in the literature [20].

\subsubsection{Construction of the electrode}

Elements that are part of a disposable syringe for insulin, a coaxial cable, a conductive epoxy resin support and a PVC membrane have been used for the construction of the selective electrodes.

\subsubsection{Preparation of the body of the electrode}

The body of the electrode was prepared [21] from a syringe of the type used for insulin (Fig. 1a-e). Small piece of copper foil, previously washed with $1: 1 \mathrm{v} / \mathrm{v} \mathrm{HCl}(\mathrm{aq})$ solution, attached to a flexible plastic ring and connected to a copper wire was placed at a distance of approximately $5 \mathrm{~mm}$ from one end of the syringe. Details of the preparation of the electrode body, the supporting epoxy conducting resin and PVC membrane are as follows.

\subsubsection{Preparation of the support}

A conductive resin (Fig. 1d) is deposited on the surface of the copper foil before depositing the sensor membrane. The conductive epoxy resin was obtained by mixing $0.1483 \mathrm{~g}$ of Araldite, $0.006 \mathrm{~g}$ of HP hardener and $0.25 \mathrm{~g}$ of graphite powder. This mixture was vigorously stirred in a suitable container by using a mechanical stirrer so that the resulting material is as homogeneous as possible. The conducting epoxy resin obtained was then deposited on the electrode body cavity with the help of a rod and was pressed against copper foil to ensure good electrical contact. The deposited epoxy resin was dried at $40{ }^{\circ} \mathrm{C}$ for at least 12 hours to complete the curing process. The surface of the resulting solid support was lowered to about $0.3 \mathrm{~mm}$ below the end of the tube in order to support the deposit of the PVC liquid membrane. 


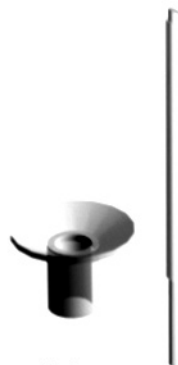

(c)

(a) (b)

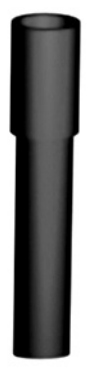

(e)

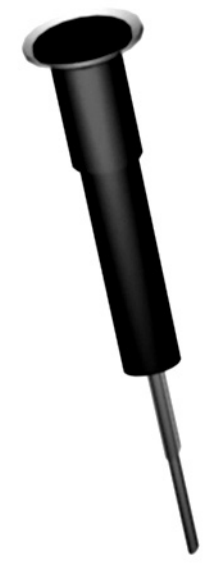

(f)
Fig. 1. Scheme of the design of the ISE. (a) membrane support, (b) coaxial cable, (c) copper foil, (d) conductive PVC membrane, (e) plastic tube (electrode body) and (f) constructed electrode.

\subsection{Determination of the electromotive force (EMF)}

The electromotive force (EMF) determinations were carried out by using an open cell at room temperature. Schematic diagram of the potentiometric cell used in this study with ion-selective electrode (ISE) as the indicator electrode and a double junction $\mathrm{Ag} / \mathrm{AgCl}$ electrode as reference is shown in Figure 2. The composition of the electrochemical cell was:
$\mathrm{Ag} / \mathrm{AgCl} \mid \mathrm{KCl}$
$0.1 \mathrm{~mol} / \mathbf{d m}^{3} \mid \mathrm{K}_{2} \mathrm{SO}_{4}$
$0.1 \mathrm{~mol} / \mathbf{d m}^{3}||$ test solution || $\mathbf{P V C m e m b}$.|cond. supp. $\mid \mathbf{C u}$

The calibration curves were used to calculate such parameters as slope (S), practical detection limit (PDL) and lower limit of linear response (LLLR). This was done following the Nernst law through data adjustment by linear regression method. The calibration parameters were obtained by applying the method of additions [22], determining the activity of the principal ion by using the Debye-Hückel equation (equation 1).

$$
-\log f=\frac{0,51 Z^{2} I^{1 / 2}}{1+I^{1 / 2}}
$$

The effect of $\mathrm{pH}$ on the response of PVC membrane electrodes was tested by using $1.0 \times 10^{-2} \mathrm{~mol} / \mathrm{dm}^{3} \mathrm{KNO}_{3}$ solution over a wide $\mathrm{pH}$ range. The $\mathrm{pH}$ was adjusted by adding sulphuric acid or sodium hydroxide solution.

The selectivity coefficients ( $K_{A B}^{\text {Pot }}$ ) were determined by using the method of mixed solutions [22] through the equation 2.

$$
K_{A B}^{P o t}=\frac{a_{A}}{a_{B}^{Z_{A} / Z_{B}}}
$$

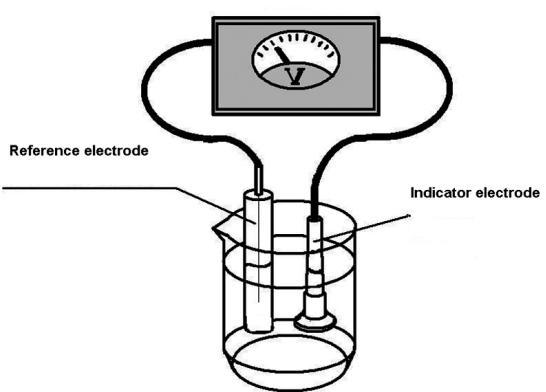

Fig. 2. Schematic diagram of the potentiometric cell used in this study with ion-selective electrode (ISE) as the indicator electrode and a double junction $\mathrm{Ag} / \mathrm{AgCl}$ electrode as reference.

\section{RESULTS AND DISCUSSION}

The analysis of the TDAN salt is presented in table 1. Together with the values reported in the literature.

Table 1. Elemental analysis of the TDAN salt.

\begin{tabular}{|c|c|c|}
\hline Element & Found (\%) & $\begin{array}{c}\text { Literature value } \\
(\mathbf{\%})^{\text {Ref.23 }}\end{array}$ \\
\hline $\mathrm{N}$ & 4.27 & 4.37 \\
\hline $\mathrm{C}$ & 75.13 & 74.94 \\
\hline $\mathrm{H}$ & 13.47 & 13.21 \\
\hline Melting point $\left({ }^{\circ} \mathrm{C}\right)$ & 106.5 & 106 \\
\hline Yeild $(\%)$ & 99 & - \\
\hline
\end{tabular}

The FT-IR spectrum of the TDAN salt is shown in Fig. 3 with the following absorption bands assignments: $\mathbf{n}_{\mathrm{CH} 2}^{\mathrm{as}}\left(2920 \mathrm{~cm}^{-1}\right), \mathbf{n}_{\mathrm{CH} 2}^{\mathrm{s}}\left(2850 \mathrm{~cm}^{-1}\right), \mathbf{d}^{\mathrm{s}}(1383$ $\left.\mathrm{cm}^{-1}\right), \mathbf{n}_{\mathrm{C}-\mathrm{N}}\left(1339 \mathrm{~cm}^{-1}\right), \mathrm{r}_{\mathrm{CH} 2}\left(720 \mathrm{~cm}^{-1}\right)$.

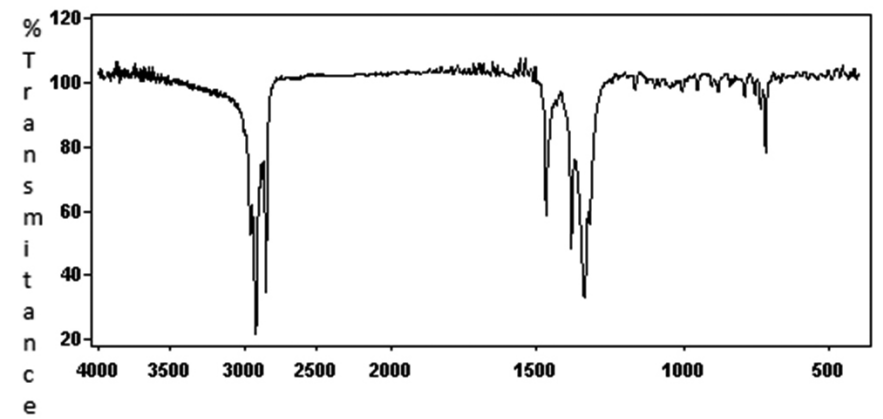

Wavenumber $\left(\mathrm{cm}^{-1}\right)$

Fig. 3. FT-IR spectrum of TDAN salt.

The potential response of the sensors prepared in this work and that of a commercially available ISE at varying concentrations of nitrate ion (Fig. 4 , calibration graph) shows linear behaviour for a wide concentration range, in the order of $10^{-6}$ to $10^{-2} \mathrm{~mol} / \mathrm{dm}^{3}$ with a slope of $-73.15 \pm 0.28 \mathrm{mV} /$ decade of activity (over Nernst). As can be seen from Table 2, the values for the slope (S) correspond to those predicted by Nernst for monovalent anions. The most sensible value of $\mathrm{S}$ corresponds to sensor constructed by using DEP as plasticizer, which is much higher than those already found for this ISE by using other plasticizers such as dibutylphthalate (DBP) and dioctylphthalate (DOP) [20]. The values obtained for the slope has the following order: DEP $(-73.15$ $\mathrm{mV} /$ decade $)>$ DOP(-61.2 $\mathrm{mV} /$ decade $)>$ DBP $(-59.6 \mathrm{mV} /$ decade $)$. These results indicate that the ISE constructed by using DBP as plasticizer showed the closest value of the slope compared to that predicted theoretically by Nernst $(-59.6 \pm 0.4 \mathrm{mV} / \mathrm{dec})$. No relation between the values obtained for the slope and physical properties of different plasticizers could be found. However, there is a consensus in the literature on the possible influence of the dielectric constant of the plasticizer in the case of divalent anions.

The detection limit was determined from the intersection of the two extrapolated segments of the calibration plots. The practical detection limit (PDL) values obtained have the following order: DEP $\left(3.53 \times 10^{-6} \mathrm{~mol} / \mathrm{dm}^{3}\right)$ $<\operatorname{DOP}\left(5.30 \times 10^{-6} \mathrm{~mol} / \mathrm{dm}^{3}\right)<\operatorname{DBP}\left(9.59 \times 10^{-6} \mathrm{~mol} / \mathrm{dm}^{3}\right)<\left(5.6 \times 10^{-4} \mathrm{~mol} /\right.$ $\left.\mathrm{dm}^{3}\right)[24]<\left(\operatorname{LPD} 10^{-5} \mathrm{~mol} / \mathrm{dm}^{3}\right)[25]$ and those obtained by the latter with a commercial electrode for nitrate, Orion 02/07/90 (LPD 10-5 mol/dm3) [26]. This allows us to affirm that electrodes constructed with the use of TDAN salt as ionophore and DEP as plasticizer can detect lower concentrations of nitrate ion.

The $\mathrm{pH}$ response profile for the sensor was tested over a wide range from $\mathrm{pH} 4-10$ by using $1.0 \times 10^{-2} \mathrm{~mol} / \mathrm{dm}^{3} \mathrm{KNO}_{3}$ solutions. The electrode potential stayed constant in all $\mathrm{pH}$ range studied. 


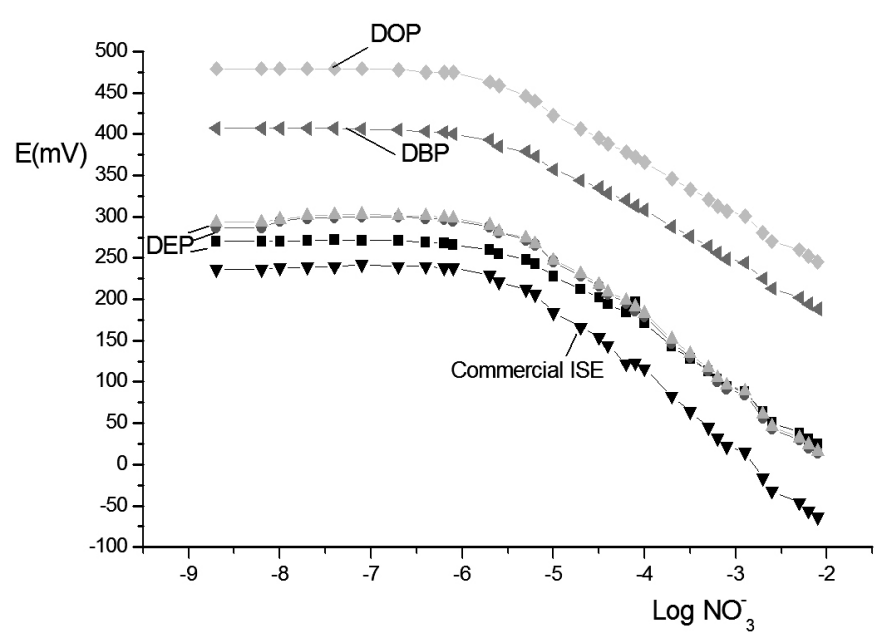

Fig. 4. Calibration curves obtained by the method of additions for sensors prepared by using DEP as plasticizer (this work) and DOP or DBP (data from Ref. 20) and that of a commercial nitrate-selective electrode (ISE) .

The effect of interfering ions on the response behaviour of the sensors was determined at a concentration of $1.0 \times 10^{-2} \mathrm{~mol} / \mathrm{dm}^{3}$ by using the mixed solution method $[22,27]$ based on the Nicolsky-Eisenman equation for potentiometric selectivity coefficients.

Table 2. Calibration parameters for the electrodes obtained by employing the addition method with DEP as plasticizer (this study) and comparison with results reported when DBP or DOP were used as plasticizers.

\begin{tabular}{|c|c|c|c|}
\hline Plasticizer & $\mathbf{D B P}^{\text {Ref. } 20}$ & DOP'Ref 20 & $\begin{array}{c}\text { (DEP) } \\
\text { This work }\end{array}$ \\
\hline $\begin{array}{c}\mathrm{S}(\mathrm{mV} / \\
\mathrm{dec})\end{array}$ & $-61.2 \pm 0.2$ & $-59.6 \pm 0.4$ & $-73.15 \pm 0.28$ \\
\hline $\begin{array}{c}\text { PDL } \\
\left(\mathbf{m o l} / \mathbf{d m}^{3}\right)\end{array}$ & $9.59 \times 10^{-6}$ & $5.30 \times 10^{-6}$ & $3.53 \times 10^{-6}$ \\
\hline $\begin{array}{c}\text { LLLR } \\
\left(\mathbf{m o l} / \mathbf{d m}^{3}\right)\end{array}$ & $2.82 \times 10^{-5}$ & $2.01 \times 10^{-5}$ & $2.49 \times 10^{-5}$ \\
\hline $\begin{array}{c}\text { Life Time } \\
\text { (months) }\end{array}$ & $>6$ & 4 & 1 \\
\hline S.D. (S) & 1.24621 & 0.81515 & 0.85123 \\
\hline $\mathbf{p H}^{\operatorname{Ref} 23}$ & $5.0-11.5$ & $5.0-11.5$ & $4.0-10$ \\
\hline $\begin{array}{l}\text { Interfering } \\
\quad \text { ion }\end{array}$ & $K_{A B}^{P o t}$ & $K_{A B}^{P o t}$ & $K_{A B}^{P o t}$ \\
\hline $\begin{array}{l}\mathrm{ClO}_{3}^{-} \\
\mathrm{BrO}_{3}^{-} \\
\mathrm{CrO}_{4}^{2-} \\
\mathrm{SO}_{4}^{2-}\end{array}$ & $\begin{array}{l}5.61 \times 10^{-1} \\
4.69 \times 10^{-2} \\
1.53 \times 10^{-3} \\
4.77 \times 10^{-4}\end{array}$ & $\begin{array}{l}6.02 \times 10^{-1} \\
2.21 \times 10^{-2} \\
1.16 \times 10^{-3} \\
2.31 \times 10^{-4}\end{array}$ & $\begin{array}{l}5.32 \times 10^{-1} \\
3.41 \times 10^{-2} \\
1.43 \times 10^{-3} \\
3.17 \times 10^{-4}\end{array}$ \\
\hline
\end{tabular}

S.D.: standard deviation.

\section{CONCLUSIONS}

The new electrode described in this work possesses high sensitivity, good stability, fast response time, wide detection limit, linear range and reproducibility toward nitrate ion. However, the electrode posses high $K_{A B}^{\text {Pot }}$ values for $\mathrm{ClO}_{3}^{-}$and $\mathrm{BrO}_{3}^{-}$anions. The proposed electrode can be used for determination of $\mathrm{NO}_{3}^{-}$ion in the concentration range of $10^{-6}$ to $10^{-2} \mathrm{~mol} / \mathrm{dm}^{3}$ and has a life-time of 1 month.

\section{REFERENCES}

[1] J. E. Zachara, R. Toczylowska, R. Pokrop, M. Zagorska, A. Dybko, W. Wróblewski, Miniaturised all-solid-state potentiometric ion sensors based on PVC-membranes containing conducting polymers, Sens. Actuat. B Chem. 101 (2004) 207-212.

[2] E. Bakker, E. Pretsch, Anal. Chem. 74(15) (2002) 420A-426A.

[3] E. Otazo, L. Pérez, O. Estévez, S. Rojas, J. Alonso, Aroylthioureas: New organic

ionophores for heavy-metal ion selective electrodes, J. Chem. Soc. Perkin Trans. 2 (2001) 2211-2218.

[4] D.Wilsona, M. de los A. Arada, S. Alegret, M. Del Valle, Lead(II) ion selective electrodes with PVC membranes based on two bis-thioureas as ionophores: 1,3-bis( $\mathrm{N}^{\prime}$-benzoylthioureido)benzene and 1,3-bis $\left(\mathrm{N}^{\prime}\right.$ furoylthioureido)benzene, J. Hazard. Mater. 181(1-3) (2010) 140-146.

[5] I. M. Kutas, E. M. Rakhmanko, I. Gonsales, V. N.Tarasevich, V. A. Vinarskii, Zh. Anal. Khim. 46(11) (1991) 2193-2196.

[6] C. R. Martin, H. Freiser, Potentiometric determination of nitrate, J. Chem. Edu., 57 (1980) 512-514.

[7] H. A. Laitinen, W. E. Harris, Análisis Químico, Reverté, Barcelona, Chapter 13, pp 253-273, 1980.

[8] P. Sánchez Batanero, Química Electroanalítica, Alhambra, Madrid, 1981, p 201.

[9] H. Higuchi and S. Motomizu, Flow-Injection Spectrophotometric Determination of Nitrite and Nitrate in biological Samples, Analyt. Sci. 15 (1999) 129-134.

[10] T. Tanial, A. Sakukagawa, T. Okutani, Monitoring of Hydrogen Peroxide, Nitrate and Nitrite in Rain Water, Analyt. Sci. 16(3) (2000) 275-281.

[11] R.A.S. Lapa, J. L. F. C. Lima, I.V.O.S. Pinto, Sequential Injection Analysis-Based System for on-Line Monitoring of Nitrite and Nitrate in Wastewaters, Analyt. Sci. 16 (2000) 1175-1160.

[12] A. S. Watts, V. G. Gavalas, A. Cammers, P. Sanchez Andrada, M. Alajarín, L. G. Bachas. Nitrate-selective electrode based on a cyclic bisthiourea ionophore, Sens. Actuat. B 121 (2007) 200-207.

[13] María de los A. Arada Pérez, Mehrdad Yardani-Pedram, Comportamiento de algunos parámetros de calibración de electrodos selectivos a Nitrato,a diferentes concentraciones del ionóforo y del disolvente mediador, Afinidad 60(505) (2003) 262-266.

[14] María de los A. Arada Pérez1, Mehrdad Yazdani-Pedram, Jorge Marín, Alejandro Speck Planche, Estudio del reconocimiento molecular de un portador movil neutro usado como electrodo all solid state a nitrato, Afinidad LXVI 540 (2009) 134-138.

[15] M. de los A. Arada, M. Yazdani-Pedram, A. Cascaret, A. Ferrer, Estudio preliminar de un ESI a nitrato con la 2-[5-(4-nitrofenil)furil]-4,5-difenil imidazol como ionóforo. Rev. Cub. Q. Vol. XV, 2, (2003) 89-94.

[16] María de los Á. Arada Pérez, Isel Cortes Nodarse, Mehrdad YazdaniPedram, Construction of a polymeric liquid-membrane ion-selective electrode (ISE) and its application for determination of nitrate in tomatoes, J. Chil. Chem. Soc. 49(1) (2004) 31-34.

[17] M. de los A. Arada Pérez, Mehrdad Yazdani-Pedram, Isel Cortes Nodars, A. R. Lazo Fraga, M. Serrano Marzabal, Determination of Nitrate in Drinking Water by Ion-Selective Electrode. Rev. Cub. Q. Vol. XV, 3, (2003) 8-13.

[18] María de los A. Arada Pérez, Mehrdad Yazdani-Pedram, J. de J. Pérez Saavedra, Sensores electroquímicos basados en sales cuaternarias de amonio, Rev. Cub. Q. Vol. XX, 1, (2008) 31-38.

[19] M. de los A. Arada Pérez, I. Cortés Nodarse, M. Yazdani-Pedram, J. J. Pérez Saavedra. Effect of Plasticizer Type on the Potentiometric Selectivity Coefficient of Electrodes for Nitrate Ion Determination Constructed by Using PVC as Polymeric Membrane, Rev. Cub. Q. .Vol. XV, 3, (2003) 36-43.

[20] M. de los A. Arada Pérez., L. Pérez Marín, J, Calvo quintana, M. YazdaniPedram, Influence of different plasticizers on the response of chemical sensors based on polymeric membranes for nitrate ion determination. Sens. Actuat. B Chem., 89(3), (2003) 262-268.

[21] Leandro León Duharte. Tesis en Opción a Máster en Química Analítica, Universidad de La Habana, Cuba, (2011).

[22] "IUPAC Compendium of Analytical Nomenclature, Oxford, Pergamon Press, pp168 - 173, 1978.

[23] D. Wegman, H. Weiss, D. Ammann, W. E. Morf, E. Pretsch, K. Sugahara, W. Simon, Anion-selective liquid membrane electrodes based on lipophilic quaternary ammonium compounds, Mikrochimica Acta [Wien] III (1984)1-16. 
[24] H. J. Nielsen, E. H. Hansen, New nitrate ion-selective electrodes based on quaternary ammonium compounds in nonporous polymer membranes, Analitica Chimica Acta, 85, (1976)1-16.

[25] J. L. F. C. Lima, A. A. S. C. Machado, A. Florido, S. Alegret, , J. M. Paulís, Nitrate- selective electrode with PVC matrix membrane applied to electrically conductive epoxy, Química Analítica, 4 (1985) 145-158.
[26] P. G. Potvin, J.- M. Lehn, in R. M. Izatt, J. J. Christensen, "Synthesis of Macrocycles: The Design of Selective Complexing Agents", Progress in Macrocyclic Chemistry, Vol. 3, Wiley, New York, 1987, p.167.

[27] María de los A. Arada Pérez, Influencia del plastificante en la respuesta al $\mathrm{pH}$ de electrodos selectivos a nitrato con sal cuaternaria de amonio, Afinidad 61(509) (2004) 59-64. 